\title{
REVIEW
}

\section{Roles of polymer brushes in biological applications}

\author{
Ajinkya Raut ${ }^{1}$ Peter Renner $^{1}$ Rick Wang $^{1}$ Serge Kazadi $^{1}$ Siddhi Mehta $^{2}$ Yan Chen $^{2}$ Hong Liang $^{1,2,{ }^{*}}$ \\ ${ }^{1}$ J. Mike Walker '66 Department of Mechanical Engineering, Texas A\&M University, TX 77843-3123, USA \\ ${ }^{2}$ Department of Materials Science \& Engineering, Texas A\&M University, TX 77843-3003, USA
}

\section{Check for updates}

Correspondence to: Hong Liang, J. Mike Walker' 66 Department of Mechanical Engineering, Texas A\&M University, TX 77843-3123, USA; \& Department of Materials Science \& Engineering, Texas A\&M University, TX 77843-3003, USA;

E-mail: hliang@tamu.edu

Received: March 26, 2021;

Accepted: April 29, 2021;

Published: April 30, 2021.

Citation: Raut A, Renner P, Wang R, et al. Roles of polymer brushes in biological applications. Adv Biochips, 2021, 2(1): 12-23.

https://doi.org/10.25082/AB.2021.01.001

Copyright: ( $) 2021$ Hong Liang, et al. This is an open access article distributed under the terms of the Creative Commons Attribution License, which permits unrestricted use, distribution, and reproduction in any medium, provided the original author and source are credited.

\begin{abstract}
Polymer brushes are macromolecular structures with polymer chains tethered to a surface resembling a brush. They have shown variety of uses in biological applications. Because of the nature of crafted polymers, the functionalized surfaces exhibit unique functions such as low friction, altered adhesion, protein binding and selective adsorption. Functionalization can be controlled by changing parameters such as grafting densities, chemical configurations, shapes and thickness. In this review, a particular emphasis has been provided for studies related to biological applications of polymer brushes based on their ultra-low friction, hydrophilic elongated surfaces, and binding properties. It provides useful information for researches and labs working on finding better solutions for drug delivery, arthritis, artificial joints, antibiofouling coatings and protein immobilization and purification.
\end{abstract}

Keywords: grafting density, drug delivery, anti-biofouling, ultra-low friction, protein immobilization

\section{Introduction}

Polymer brushes are comprised of polymer chains which connect on one end to a surface and extend approximately normal to the surface, giving them the appearance of a brush. One of their main properties is called grafting density, which is the number of polymers attached to the surface in a given area. Grafting density controls the morphology of polymer brushes. Low graft density results in a mushroom morphology for each polymer while high grafting density results in an upright morphology [1]. Their unique properties are partially dependent on grafting density; thus polymer brushes are so appealing due to the ability to control grafting density.

Polymer brushes were first explained theoretically in the 1970s studying polymer chains with a polar head adsorbing onto a surface [2], followed by experimental fabrication in the 1980s [3-6]. However, while a new and innovative surface modification technique, not many useful applications polymer brushes were initially found. Thus, most early studies focused on effect of grafting density on polymer brush height, developing theory which matches experimental findings, and simulation and modeling of polymer brushes $[1,3-5,7,8]$. In 2003 it was discovered that electrically charged polymer brushes result in each polymer pushing away from its neighbors, increasing the overall height of the polymer brush [9]. This resulted in coefficient of friction (COF) as low as 0.0006 or even lower. Once the attractive effect of charged polymer brushes on COF were discovered, the majority of research has focused on the modification of the tribological properties of polymer brushes. Due to their excellent tribological properties, three dimensional structures, hydrophilicity, and water-swelling properties, they became a prime study subject for biological applications. Table 1 presents the most related publications on the low frictional properties of polymer brushes since 2003, along with major findings.

\section{Synthesis route for surface functionalization}

The structure of polymer brushes is made of closely packed monolayers of macromolecules. These monolayers can be utilized to produce under control multiple nanostructures to form a surface. As a result, these nanostructures are becoming a significant platform for the material science and engineering due to the fact that they can be used to construct surfaces previously impossible to fabricate. The fabrication of a surface using the polymer brushes is accomplished by grafting chemically.

There are currently two principal strategies to fabricate a surface by grafting the polymer brushes on a desired substrate. These two principal strategies are named the "grafting-onto" and 
"grafting-from" as indicated by Figure 1 [23]. The Grafting-onto approach engages the processes of physisorption and chemisorption. This approach consists of grafting pre-synthesized polymers chains that have already desired length. A polymer is a chain made of single elements called monomers which are linked. For this method to work, each of the polymers must have a chain-end within functional groups. The polymer chain-end is required to have either a high affinity to the substrate or its complementary elements. The complementary elements can be coated on the substrate to serve as a bonding to the polymer brushes if needed [23]. The grafting-onto strategy is difficult to control when a specific result is desired. This is due to the polymers coiling preventing to increase the grafting density. As a result, this method is less used to fabricate the polymer brushes.

The polymer brushes grafting-from method also uses the processes of physisorption and chemisorption. Contrary to the grafting-onto strategy, this approach consists of attaching monomers instead of polymers. As a result, the fabrication density of the polymer brushes can be easily controlled to achieve a desired result. Based on this, the grafting-from strategy is

Table 1 Publications on the tribological properties of polymer brushes

\begin{tabular}{|c|c|c|c|c|}
\hline Polymer brush & Focus of study & Major findings & Published & Reference \\
\hline PMMA- $b$-PSGMA & $\begin{array}{l}\text { Effect of charged polymers } \\
\text { on polymer brushes }\end{array}$ & $\begin{array}{l}\text { Charged polymer brushes } \rightarrow \\
\mathrm{COF} \sim 0.001\end{array}$ & 2003 & [9] \\
\hline PMMA & $\begin{array}{l}\text { In-depth study of } \\
\text { tribological properties }\end{array}$ & $\begin{array}{l}\mathrm{COF}_{\text {PMMA brush }}< \\
\mathrm{COF}_{\mathrm{PMMA}} \text { film, tribological } \\
\text { properties rely on solution }\end{array}$ & 2005 & [10] \\
\hline MPC & $\begin{array}{l}\text { Effect of high-density } \\
\text { polymer brush on COF } \\
\text { various environments }\end{array}$ & $\begin{array}{l}\text { Extremely low COF can be } \\
\text { achieved at high density even in } \\
\text { humid air }\end{array}$ & 2007 & [11] \\
\hline pMPC & $\begin{array}{l}\text { Polymer brush comparison } \\
\text { to synovial joints }\end{array}$ & $\begin{array}{l}\text { Lubrication of polymer brush } \\
\text { comparable to synovial joint }\end{array}$ & 2009 & {$[12]$} \\
\hline PMMA, PS, PNIPAM & $\begin{array}{l}\text { Effect of stretching chains } \\
\text { of polymer brushes }\end{array}$ & $\begin{array}{l}\text { Stretched chains have better } \\
\text { tribological properties than } \\
\text { unstretched }\end{array}$ & 2009 & {$[13]$} \\
\hline $\begin{array}{l}\text { PMPC, PHEMA, } \\
\text { PMMA }\end{array}$ & $\begin{array}{l}\text { Nanoscale characterization } \\
\text { of polymer brushes }\end{array}$ & $\begin{array}{l}\text { Friction resistance highly correlated } \\
\text { to water absorptivity of } \\
\text { polymer/hydrated layer }\end{array}$ & 2009 & [14] \\
\hline PMIS, PHMA & $\begin{array}{l}\text { Effect of using poly(ionic } \\
\text { liquid) brush }\end{array}$ & $\begin{array}{l}\text { Poly(ionic liquid) brush held much } \\
\text { lower COF for many more cycles } \\
\text { than regular polymer brush }\end{array}$ & 2010 & [15] \\
\hline PS & $\begin{array}{l}\text { Effect of solvent quality on } \\
\text { lubrication of polymer } \\
\text { brush }\end{array}$ & $\begin{array}{l}\text { Degree of polymer brush height can } \\
\text { be controlled by solvent quality }\end{array}$ & 2011 & {$[16]$} \\
\hline MPC & $\begin{array}{l}\text { High pressure polymer } \\
\text { brushes using } \\
\text { grafting-from technique }\end{array}$ & $\begin{array}{l}\text { COF remained as low as } 0.001 \text { even } \\
\text { at a pressure of } 7.5 \mathrm{MPa}\end{array}$ & 2011 & [17] \\
\hline MTAC, SPMK & $\begin{array}{l}\text { Studied oppositely charged } \\
\text { polymer brush interaction }\end{array}$ & $\begin{array}{l}\text { Nanoscale adhesion was } \\
\text { accomplished using polymer } \\
\text { brushes with opposite charges }\end{array}$ & 2011 & [18] \\
\hline PMMA & $\begin{array}{l}\text { Studied effect of fluid } \\
\text { viscosity on lubrication of } \\
\text { polymer brushes }\end{array}$ & $\begin{array}{l}\text { High-viscosity solvents resulted in } \\
\text { hydrodynamic lubrication with } \\
\text { COF depending on shear velocity }\end{array}$ & 2012 & [19] \\
\hline $\begin{array}{l}\text { PFA-C }_{8}, \text { PMMA, } \\
\text { PDHMA, PVA, } \\
\text { PEGMA, } \\
\text { PDMAEMA, PMANa, } \\
\text { PMTAC, PSPMK, } \\
\text { PDMAB, PMAPS, } \\
\text { PMPC }\end{array}$ & $\begin{array}{l}\text { In-depth wettability study } \\
\text { of polymer brushes }\end{array}$ & $\begin{array}{l}\text { Surface energy and wettability was } \\
\text { heavily affected depending on } \\
\text { whether ionic liquid or nonionic } \\
\text { liquid was used }\end{array}$ & 2012 & {$[20]$} \\
\hline $\begin{array}{l}\text { P18MA, P12MA, } \\
\text { P6MA }\end{array}$ & $\begin{array}{l}\text { Studies polymer brushes in } \\
\text { oil }\end{array}$ & $\begin{array}{l}\text { COF was greatly reduced at } \\
\text { pressures as high as } 450 \mathrm{MPa}\end{array}$ & 2012 & {$[21]$} \\
\hline PMTAC & $\begin{array}{l}\text { Studied the formation of a } \\
\text { boundary lubrication layer } \\
\text { of polymer brushes }\end{array}$ & $\begin{array}{l}\text { Increasing velocity greatly } \\
\text { increased gap thickness and } \\
\text { reduced COF }\end{array}$ & 2014 & [22] \\
\hline
\end{tabular}




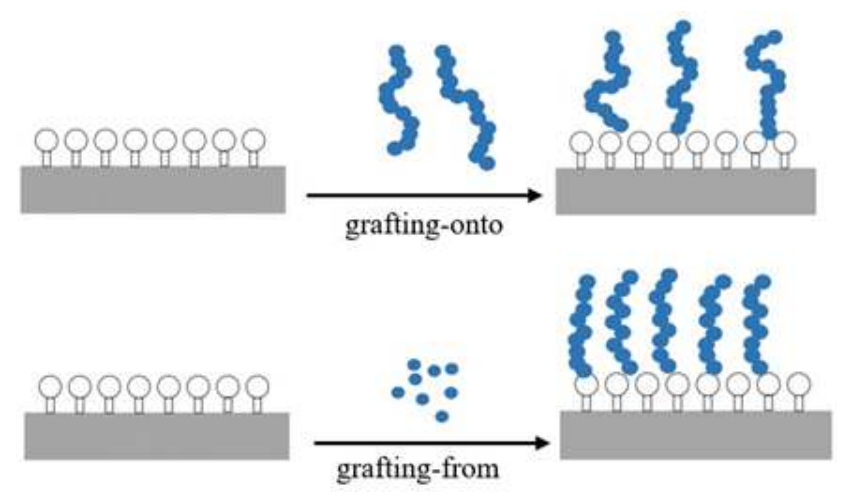

Figure 1 Grafting-onto and Grafting-from strategies (redrawn from [23])

also called the bottom-up approach since the polymer chains are grown from single elements or monomers. The polymer chains are cultivated via a surface-initiated polymerization (SIP) according to Mocny and Klok [23].

To fabricate the polymer brushes, there are a variety of devices used in the process. Figure 2 shows one of such devices [24]. It consists of a chamber containing a chemical solution made of a monomer, $\mathrm{CuCl}, \mathrm{CuCl} \mathrm{Cl}_{2}, \mathrm{BiPy}$, and a solvent at the bottom. The upper section of the chamber has a nitrogen blanket. A micropump is also part of the device. The surface of the substrate on which the polymer brushes are to be grafted is submerged into the chemical solution. The longer the substrate stays submerged in the solution, the longer the polymer brushes get. The chemical solution is drained out with the micropump to stop the growth of the polymer brushes. The chemical draining also allows a gradient based molecular size as indicated by the side view.

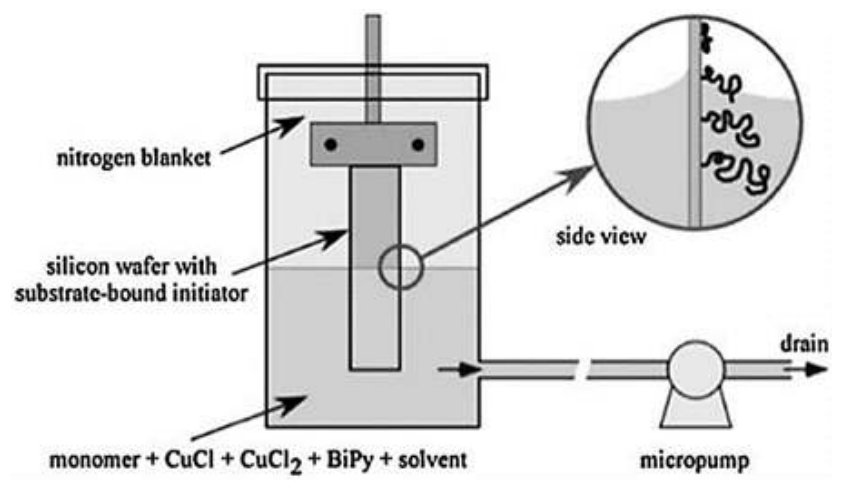

Figure 2 Device for creating surface- grafted polymer (used with permission [24])

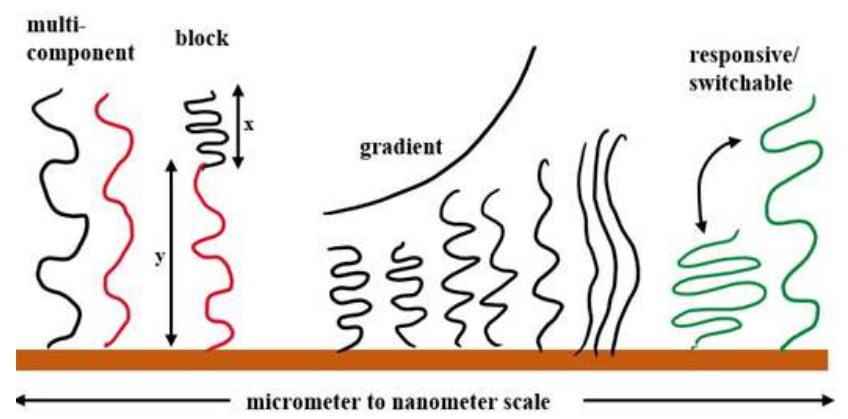

Figure 3 Polymer brush configurations (redrawn from [24])

Polymer brushes can be grafted with different configurations (Figure 3). These configurations are the multi-component, block, gradient, and responsive or switchable. The multi-component consists of alternating chemically different polymers. The block configuration involves the grafting of a polymer brush on top of a different polymer brush. The gradient configuration 
simply changes the polymer brush length or molecular size. The responsive or switchable entails different regimes of polymer brushes also on the same surface of the substrate.

\section{Characteristics and bio-based applications of poly- mer brush}

Many of the characteristics of polymer brushes have been studied recently and thus the polymer brushes have found their resourcefulness into many applications. One of the important properties of polymer brushes is that they produce very low friction coefficients in aqueous medium. This property can be utilized to mimic synovial joints found in mammals [25]. When compared to other polymers, the polymer brushes possess unimolecular as well as intramolecularly assembled nanostructures with varying properties. These nanostructures of appropriate size range could be used to avoid fast systemic clearance and hence polymer brushes have drastically gained interest for drug delivery [26]. The polymer brush coatings can be looked as tethered polymer with hydrophilic long chains dangling in the surrounding. These highly hydrated layers on the surface increases osmotic pressure when a bacterium is nearby which results into the repulsion of bacteria from the surface. Thus, the polymer brush coatings act like a bacteria barrier and has found useful applications as antibiofilm [27]. The three-dimensional and water-swollen structure of polymer brushes provide sufficient accessible volume to bind many protein monolayers. These properties make them attractive for protein immobilization and purification applications. These high increase in binding capacity can be used to enhance the sensitivity and efficiency of analytical devices [28]. This section presents some of the prime biological applications of polymer brushes.

\subsection{Lubrication of synovial joints}

The polymer brush is essential in the bio-lubrication of synovial joint. Synovial joints connect bones and support the movement in mammals. These joints have contacting cartilage which lubricated with fluid called synovial fluid. Synovial joint shows low coefficient friction of unfavorable tribological conditions. It also resists wear. At a pressure larger than $5 \mathrm{MPa}$ the coefficient of friction is lower than 0.002 . The reason behind their superior tribological performance lays in the molecular structure of the cartilage surface. The surface of the synovial joint cartilage has a polymer brush like structure. This structure combined with the synovial fluids, provides the high wear resistance and the low coefficient of friction in the joint.

There is significant potential in bio-mimic design of synovial joints [29]. The lubricated polymer brush presented a novel lubricating method, the hydration lubrication [30,31]. The low friction at high pressure is also attractive to many different engineering applications. It also offers a potential solution to lubricate the replaced synovial joint [29].

Polymer brushes can greatly enhance the fluidic lubrication despite its poor performance in dry sliding condition [32]. The Kobayashi et. al. compared the coefficient of friction for multiple hydrophilic polymer brushes [32]. Among them, the lowest coefficient of friction in dry nitrogen is around 0.1 of the Poly(OEGMA) brush. The dry sliding poly(SPMK), despite its ultralow friction when lubricated in water (around 0.02), displayed the highest friction in dry nitrogen ( 0.4 approximately). This finding indicated that, like the cartilage in synovial joint, the key to the low friction in polymer brush is the fluid-polymer interaction. In addition, this low friction state cannot be achieved when lubricating water contains $1000 \mathrm{mM} \mathrm{NaCl}$. Further proves that the importance of fluid-polymer interaction.

In order to further discuss the lubricating with fluid, the concept of Stribeck curve have to be introduced. The Stribeck curve indicated that the coefficient of friction of a fluidic lubricated system is controlled by the Sommerfeld number, which is proportional to the entrapment speed, viscosity of fluid and the inverse of load. At the high Sommerfeld number, fluidic film separated surfaces, result friction from hydrodynamic drag. At low Sommerfeld number, the fluidic film is thinner than the surface roughness which leads to contact and high friction. In Bielecki et. al., the Stribeck curve of polymer brushes and bear surfaces lubricated by oil is presented [33]. All the curves collapse into two separate behaviors, the bear surfaces and the polymer brushes. It appears that the polymer brush extended the hydrodynamic lubrication regime thus lowering the coefficient of friction [33]. This extension of hydrodynamic regime can be attributed to the hydration effect of poly(dodecyl methacrylate) due to its rich branches [34].

The branched and linear polymer brush shows different tribological performances. In both the case of aqueous lubrication and oil lubrication, the branched polymer chain (Figure 4) shows a superior tribological performance. In the studies of water lubrications, the branched 
poly(SPMK) shows better performance [32], while in the oil lubricated polymer brush branched poly(dodecyl methacrylate) has the lowest friction [33,35]. It is also worth noting that the polymer brushes in synovial joints are branched. This may indicate this branched structure can employ the "squeeze film" effect of the polymer brush.

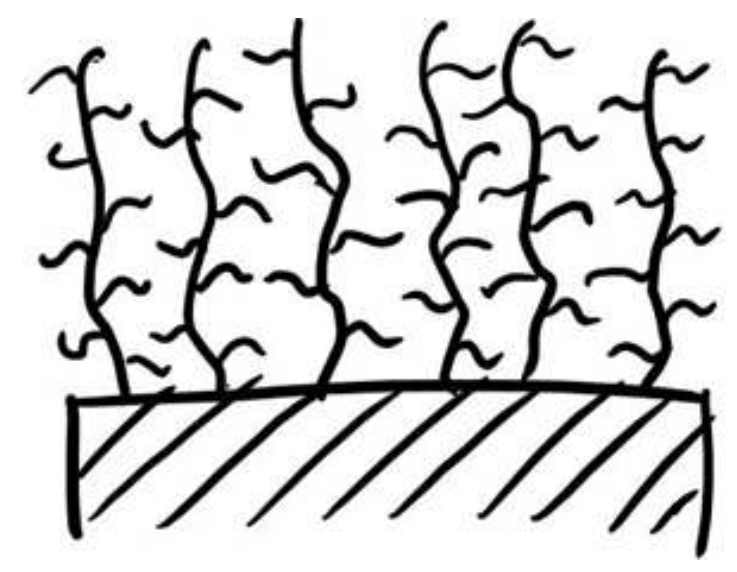

Figure 4 The schematic representation of a branched polymer chain

The polymer brush's tribological property can be further improved with electrochemical forces. Both branched hydrophilic polymer brush and oil compatible polymer brush can only achieve the coefficient of 0.01 , one order of magnitude lower than synovial joints. However, the charged polymer brush such as polyzwitterionic polymer brush present the best tribological properties that raveled synovial joints [31]. In aqueous solutions, the charged polymer chain can interact with each other and further reduce the friction. Raviv et. al. compares the coefficient of friction of three charged polymer configuration with the polymer chain volume fraction [31]. They conclude that the charged polymer chain can achieve far lower friction compare to the uncharged. The charged polymer brush created a hydration layer, surrounded by the swollen polymer chain $[31,36]$. This separation created by the electric force reduced the friction down to 0.001 .

A molecular dynamics simulation was constructed by using nanoscale polymer model of a polymer brush system to better understand the lubrication of articular cartilage [37]. They analyzed the frictional properties by using chondroitin 6-sulphate molecules grafted on resilient surface as the polymer brush and water with sodium ions as the synovial liquid. This study concluded that the large deformation of the polymers and the deviation of the synovial fluids from the Coutette flow leads to drastic reduction in friction and that the longer the chains of polymer, larger the friction reduction. Hairy polyelectrolyte brushes fabricated from poly (3-sulfopropyl methacrylate potassium salt) (PSPMK) grafted in poly ( $\mathrm{N}$-isopropylacrylamide) (PNIPAAm) microgels were demonstrated to be used as intelligent synovial fluid system [38]. Under soft friction pairs, coefficient of friction as low as 0.005-0.015 were obtained. They also demonstrated temperature sensitive drug release capabilities.

\subsection{Drug delivery}

Due to their versatile properties, polymers are used broadly for drug deliveries. The unimolecular and also intermolecularly assembled nanostructures with varied properties in the polymer brushes helps in drug delivery. And hence, the drug delivery via polymer brush-based scaffolds have attracted a lot of attention recently [39]. Drugs are integrated with the polymer brushes with adaptable structures and features by physical encapsulation or chemical conjugations to build the drug delivery systems. These types of systems are called as brush polymer-drug conjugate (BPDC) systems. To tackle the deadly disease cancer, the delivery of anticancer drugs using polymer brush systems have invited a lot of attention. It is very important to maintain specific considerations and control the dimensions of the scaffolds used for drug delivery in range of 10-200 $\mathrm{nm}$ to restrict the clearance and to help tumor targeting via the EPR effect [40].

Doxorubicin (DOX) is widely used medicine in chemotherapy for treatment of cancer. The drug delivery time and dosage are of particular importance for DOX. There have been a lot of studies where polymer brush-based mechanisms have been successfully tested for delivery of DOX as well as other drugs in the desired content and region. Table 2 contains the list of recent works where polymer brush-based systems are used for drug delivery in detail. In one 
of the study, the drug delivery system was conjugated with polylactide based biodegradable polymer brush for testing for chemotherapy drug release [41]. When comparing cytotoxicity of the BPDC based drug release and the free DOX, the researchers found that the BPDC was more therapeutically effective towards MCF-7 cells when the concentrations were 5 and $10 \mu \mathrm{g} \mathrm{mL}^{-1}$. The drug release was time and $\mathrm{pH}$ responsive as well.

Table 2 Polymer brush-based drug delivery systems

\begin{tabular}{|c|c|c|c|}
\hline Drug & Polymer brush technique & Usage & Reference \\
\hline Doxorubicin (DOX) & $\begin{array}{l}\text { Polylactide (PLA)-based } \\
\text { biodegradable scaffolds }\end{array}$ & Cancer treatment & [41] \\
\hline Doxorubicin (DOX) & $\begin{array}{l}\text { Poly (2-hydroxyethyl methacrylate) } \\
\text { (PHEMA) and PCL-b-PEG block } \\
\text { copolymers }\end{array}$ & Cancer treatment & [42] \\
\hline Doxorubicin (DOX) & $\begin{array}{l}\text { Densely grafted PCL-b-PEO onto a } \\
\text { functionalized polymethacrylate } \\
\text { (PGA) }\end{array}$ & Cancer treatment & [43] \\
\hline $\begin{array}{l}\text { Camptothecin (CT), } \\
\text { Doxorubicin (DOX) }\end{array}$ & $\begin{array}{l}\text { bivalent-brush polymers; prepared } \\
\text { by graft-through ROMP of } \\
\text { drug-loaded PEG based } \\
\text { macromonomers }\end{array}$ & Cancer treatment & [44] \\
\hline Doxorubicin (DOX) & $\begin{array}{l}\text { Core-Clickable PEG-Branch-Azide } \\
\text { Bivalent-Bottle-Brush Polymers by } \\
\text { ROMP }\end{array}$ & Cancer treatment & [45] \\
\hline Paclitaxel (PTXL) & $\begin{array}{l}\text { A degradable BPDC synthesized } \\
\text { through azide-alkyne click reaction } \\
\text { of acetylene-functionalized PLA } \\
\text { with azide-functionalized PTXL } \\
\text { and poly(ethylene glycol) (PEG) }\end{array}$ & Cancer treatment & [46] \\
\hline Paclitaxel (PTXL) & $\begin{array}{l}\text { Diblock BPDC of Poly (ethylene } \\
\text { glycol) (PEG)-based } \\
\text { macromonomer }\end{array}$ & Cancer treatment & [47] \\
\hline $\begin{array}{l}\text { Ibuprofen (IBU), } \\
\text { poorly water-soluble } \\
\text { drugs }\end{array}$ & $\begin{array}{l}\text { Poly (methyl } \\
\text { methacrylate-co-methacrylic } \\
\text { acid)-b-poly(poly(ethylene glycol) } \\
\text { methyl ether mono-methacrylate) } \\
\text { [P(MMA-co-MAA)-b-PPEGMA] } \\
\text { synthesized by ATRP technique }\end{array}$ & Painkillers & [48] \\
\hline Aspirin (ASA) & $\begin{array}{l}\text { PSPMK brushes grafted PNIPAAm } \\
\text { microgels }\end{array}$ & $\begin{array}{l}\text { Reduce fever, muscle } \\
\text { aches }\end{array}$ & [38] \\
\hline
\end{tabular}

\subsection{Anti-biofouling}

One the biggest barriers in tissue engineering are the non-specific bacteria adhesion and protein adsorption. Understanding the fundamentals of nature's non-fouling conditions for these proteins and bacteria have given rise to environment friendly ultra-low fouling initiatives $[49,50]$. The two strategies developed for this purpose are; contact killing and use of an anti-fouling material [51-53]. Due to the higher grafting density as well as the molecular weight, the surface modified with the polymer brush exhibited a better performance than the self-assembled monolayers (SAMs) surfaces $[54,55]$. Recently, the zwitterionic polymer has attracted a lot of attention as a replacement of PEGylation, due to their chemical diversity [56-59]. Another method to integrate anti-biofouling properties in these films is ester hydrolysis $[58,60]$.

Grafting polymer brushes is an effective strategy to prevent biofouling. This is attributed to the chemical strength of the surface modified via polymer brushes [61-65]. However, despite the resistance exhibited by these components, drawbacks like the short working period and single anti-fouling mechanism, need to be overcome. One way to prevent this is using multiple component surfaces. Combining the structural and surface chemistry of these materials is vital for developing its anti-biofouling properties [66]. For instance, in recent study, a NIPAM polymer brush was made inspired by the feet of the Gecko. It showed a significant decline in green algae adhesion [67]. Table 3 lists a collection of recent studies that proves antibiofouling nature of polymer brushes and their various applications. 
Table 3 Polymer brush systems used for anti-biofouling applications

\begin{tabular}{|c|c|c|}
\hline Polymer brush system & Properties/Applications & References \\
\hline $\begin{array}{l}\text { 3-(trimethoxysilyl) propyldimethyloctadecylammonium } \\
\text { chloride coating of silicone rubber }\end{array}$ & $\begin{array}{l}\text { Antimicrobial surface coatings } \\
\text { (gram-positive and gram-negative) }\end{array}$ & {$[51]$} \\
\hline $\begin{array}{l}\text { Cross-linked hyperbranched fluoropolymer (HBFP) and } \\
\text { poly(ethylene glycol) (PEG) coatings on 3-APS glass slides }\end{array}$ & $\begin{array}{l}\text { Green fouling resistance, marine } \\
\text { antifouling }\end{array}$ & {$[52]$} \\
\hline $\begin{array}{l}\text { zwitterionic poly(carboxybetaine methacrylate) (pCBMA) on } \\
\text { glass surface }\end{array}$ & $\begin{array}{l}\text { Resistance to bacterial biofilm } \\
\text { formation (P. aeruginosa and } \mathrm{P} \text {. } \\
\text { putida) }\end{array}$ & {$[54]$} \\
\hline Hydrogels carboxybetaine derivatives & $\begin{array}{l}\mathrm{pH} \text { controlled antibacterial } \\
\text { (E.Coli.), strong mechanical } \\
\text { properties }\end{array}$ & {$[58]$} \\
\hline $\begin{array}{l}\text { [2-(methacryloyloxy)ethyl] trimethylammonium chloride and } \\
\text { 3-sulfopropyl methacrylate potassium salt }\end{array}$ & $\begin{array}{l}\text { Non fouling properties due to } \\
\text { oppositely charged monomers being } \\
\text { polymerized together }\end{array}$ & [59] \\
\hline $\begin{array}{l}\text { PDMAEMA, PSPMA, PHEMA-co-PEG10MA, and PSBMA } \\
\text { polymer brushes }\end{array}$ & Low marine biofouling & {$[62]$} \\
\hline $\begin{array}{l}\text { poly(3-sulfopropylmethacrylate) grafted on sylgard-184 } \\
\text { silicone elastomer and resorcinol formaldehyde }\end{array}$ & $\begin{array}{l}\text { Inhibition of settlements of } \\
\text { microalgae and facilitation of cell } \\
\text { release due to the microspines }\end{array}$ & {$[66]$} \\
\hline PAA gel micro-brushes & $\begin{array}{l}\text { Underwater superoleophobic } \\
\text { properties, antifouling properties } \\
\text { against algae }\end{array}$ & {$[67]$} \\
\hline
\end{tabular}

Table 4 Polymer brush for protein immobilization applications, their binding methods and uses

\begin{tabular}{llll}
\hline Polymer brush & Binding method & Applications/uses & Reference \\
\hline $\begin{array}{l}\text { Repetitive iminodiacetic acid chains } \\
\text { polymer brush }\end{array}$ & $\begin{array}{l}\text { Selective binding of } \\
\text { histidine-tagged recombinant } \\
\text { proteins }\end{array}$ & $\begin{array}{l}\text { Biosensors, drug delivery, } \\
\text { proteomics }\end{array}$ & [71] \\
\hline $\begin{array}{l}\text { Mixed polymer brushes of } \\
\text { poly(ethylene oxide) (PEO), and } \\
\text { poly(acrylic acid) (PAA) }\end{array}$ & $\begin{array}{l}\text { Selective protein adsorption from a } \\
\text { mixture of lysozyme (Lyz), human } \\
\text { serum albumin (HSA), and human } \\
\text { fibrinogen (Fb) }\end{array}$ & $\begin{array}{l}\text { Responsive bio-interfaces } \\
\text { in the fields of } \\
\text { nanomedicines, biosensors, } \\
\text { smart medicines }\end{array}$ & [70] \\
\hline $\begin{array}{l}\text { Poly(2-hydroxyethyl methacrylate) } \\
\text { (PHEMA) brushes in porous } \\
\text { alumina }\end{array}$ & $\begin{array}{l}\text { Protein adsorption, 150 mg of } \\
\text { protein/ cm }{ }^{3} \text { (bovine serum } \\
\text { albumin) }\end{array}$ & $\begin{array}{l}\text { Purification of His-tag } \\
\text { proteins }\end{array}$ \\
\hline $\begin{array}{l}\text { Coating of poly(acrylic acid) (PAA) } \\
\text { plus activation of the free -COOH } \\
\text { groups }\end{array}$ & $\begin{array}{l}\text { Reaction with amine groups, } \\
\text { covalent immobilization, selective } \\
\text { binding }\end{array}$ & $\begin{array}{l}\text { Drug testing, medical } \\
\text { diagnostics, proteomics }\end{array}$ \\
\hline $\begin{array}{l}\text { Poly(oligo(ethylene glycol) } \\
\text { methacrylate) (POEGMA) brushes }\end{array}$ & $\begin{array}{l}\text { Direct protein coupling } \\
\text { (streptavidin) }\end{array}$ & $\begin{array}{l}\text { Recognition of specific } \\
\text { macromolecules for } \\
\text { medical diagnostics, } \\
\text { biofunctionalization }\end{array}$ \\
\hline
\end{tabular}

\subsection{Protein immobilization and purification}

Polymer brushes can bind to many monolayers of protein because of their three-dimensional structures. Thus, polymer brushes provide great attraction for protein immobilization and purification. This would enhance the sensitivity and efficiency of many analytical devices like protein microarrays, membrane absorbers and matrix-assisted laser desorption ionization (MALDI) plates used for protein capture. Variety of studies where polymer brushes are used for immobilizing protein have been published. One of the method uses poly(2-hydroxyethyl methacrylate) (PHEMA) brushes in porous alumina made by ATRP to bind proteins [68]. The rapid protein binding and high efficiency of these membranes could be useful in purification of protein. Dai et. al. [69] used poly(acrylic acid) (PAA)/protonated poly(allylamine) (PAH) coatings for covalent immobilization of microarrays of antibodies. This process demonstrates selective binding of proteins to bio-specific molecules as it resists nonspecific adsorption and allow for covalent immobilization. The PAA polymer brushes are highly studies for protein immobilization because in aqueous conditions they could swell three to four times and facilitate binding of larger biomolecules. Mixed polymer brushes composed of PEO and PAA were 
developed to test the selective protein adsorption from a mixture of lysozyme (Lyz), human serum albumin (HSA), and human fibrinogen $(\mathrm{Fb})$ [70]. They demonstrated that by controlling the ionic strength, the electrostatic interactions can be controlled, and thus selective adsorption can be achieved. These kinds of materials can be used as biosensors, and smart medicines. Table 3 compiles the studies done on polymer brushes and their applications related to protein immobilization in the recent years. Table 4 contains a list of highly cited papers relevant to this section and their probable applications.

\section{Summary}

This work reviewed the different synthesis routes of polymer brush, their resourceful characteristics, and applications in the biological and biomedical field. Polymer brushes can be modified according to grafting density and monomers, giving flexibility in properties and applications. The characteristics of polymer brushes were discussed according to their different applications: as lubricants, for drug delivery, anti-biofouling, and protein immobilization and purification.

\subsection{Ultra-low friction}

It was found that polymer brushes function similar to that of the synovial joint in the human knee, resulting in hydration lubrication. In artificial joints, polymer brushes are currently being researched as one alternative, showing significant friction reduction compared to current materials.

\subsection{Drug delivery}

The unimolecular and intramolecularly arranged nanostructures of polymer brushes can be utilized to avoid fast systemic clearance which enhances their drug delivery applications. PBDC systems are already successfully tested for cancer treatments, painkillers, and pain relievers. Drugs systems are built by physical encapsulation or chemical conjugations of drugs integrated with polymer brushes.

\subsection{Anti-biofouling}

Various opportunities exist for the polymer brush in anti-biofouling due to the higher grafting densities and molecular weights. The highly hydrophilic long chains of polymer brushes can be used to repel bacteria and other biofouling elements. Fundamental understanding of the structural and surface chemistry of these materials is vital for developing its anti-biofouling properties.

\subsection{Protein immobilization and purification}

The 3D and water-swollen structure of polymer brushes intensifies the binding protein monolayers. These properties enable them to be used for protein immobilization and purification. They can be used to manufacture smart medicines and biosensors.

\section{Recommendations}

(1) Currently, the applications of polymer brushes are limited to small scale uses and research. This is especially true in lubrication in artificial joints as further research is needed to evaluate its feasibility.

(2) The main limiting factor of brushes in industry applications is the issue of high load and limited wear life since high loads and stresses accelerate the degradation of polymer brushes. Because of this, large scale industrial applications have yet to be put into practice.

(3) Newer research is being done on developing "smart" polymer brushes. The research should focus on using polymer brushes to build micro and nano structure and modifying them to be able to respond to very specific stimuli. Their chemical as well physical properties can be immensely improved with change in the length scale of the polymer.

(4) The coefficient of friction of the polymer chains can be improved by upto one order of magnitude by electrochemical forces. 
(5) Focus on PAA polymer brushes is needed for protein immobilization. They swell up to three to four times in aqueous medium, they are of great asset in the field.

(6) Poly(SMPK) brushes in aqueous solutions displayed good results against wear resistance for around 500 cycles. Their modifications should be looked thoroughly for long lasting wear resistive polymer brushes.

\section{Conflict of interests}

There are no conflicts to declare.

\section{Acknowledgements}

Peter Renner was supported by the National Science Foundation (NSF) Graduate Research Fellowship.

\section{References}

[1] Murat M and Grest GS. Structure of a grafted polymer brush: a molecular dynamics simulation. Macromolecules, 1989, 22(10): 4054-4059.

https://doi.org/10.1021/ma00200a041

[2] Alexander S. Adsorption of chain molecules with a polar head a scaling description. Journal De Physique, 1977, 38(8): 983-987. https://doi.org/10.1051/jphys:01977003808098300

[3] de Gennes P. Conformations of polymers attached to an interface. Macromolecules, 1980, 13(5): 1069-1075. https://doi.org/10.1021/ma60077a009

[4] Milner ST, Witten TA and Cates ME. Theory of the grafted polymer brush. Macromolecules, 1988, 21(8): 2610-2619. https://doi.org/10.1021/ma00186a051

[5] De Gennes P. Polymers at an interface: a simplified view. Advances in Colloid \& Interface Science, 1987, 27(3-4): 189-209. https://doi.org/10.1016/0001-8686(87)85003-0

[6] Milner S, Witten T and Cates M. Effects of polydispersity in the end-grafted polymer brush. Macromolecules, 1989, 22(2): 853-861. https://doi.org/10.1021/ma00192a057

[7] Milner ST. Polymer brushes. Science, 1991, 251(4996): 905-914. https://doi.org/10.1126/science.251.4996.905

[8] Halperin A, Tirrell M and Lodge T. Tethered chains in polymer microstructures. In: Macromolecules: Synthesis, Order and Advanced Properties. Springer,1992: 31-71. https://doi.org/10.1007/BFb0051635

[9] Raviv U, Giasson S, Kampf N, et al. Lubrication by charged polymers. Nature, 2003, 425(6954): $163-165$. https://doi.org/10.1038/nature01970

[10] Sakata H, Kobayashi M, Otsuka H, et al. Tribological properties of poly (methyl methacrylate) brushes prepared by surface-initiated atom transfer radical polymerization. Polymer Journal, 2005, 37(10): 767-775 https://doi.org/10.1295/polymj.37.767

[11] Kobayashi M, Terayama Y, Hosaka N, et al. Friction behavior of high-density poly (2 methacryloyloxyethyl phosphorylcholine) brush in aqueous media. Soft Matter, 2007, 3(6): 740-746. https://doi.org/10.1039/b615780g

[12] Chen M, Briscoe WH, Armes SP, et al. Lubrication at physiological pressures by polyzwitterionic brushes. science, 2009, 323(5922): 1698-1701. https://doi.org/10.1126/science.1169399

[13] Tsujii Y, Nomura A, Okayasu K, et al. AFM studies on microtribology of concentrated polymer brushes in solvents. In IOP Publishing, 2009: 012031. https://doi.org/10.1088/1742-6596/184/1/012031

[14] Kitano K, Inoue Y, Matsuno R, et al. Nanoscale evaluation of lubricity on well-defined polymer brush surfaces using QCM-D and AFM. Colloids Surf B Biointerfaces, 2009, 74(1): 350-357. https://doi.org/10.1016/j.colsurfb.2009.08.004

[15] Ishikawa T, Kobayashi $M$ and Takahara A. Macroscopic frictional properties of poly (1-(2methacryloyloxy) ethyl-3-butyl imidazolium bis (trifluoromethanesulfonyl)-imide) brush surfaces in an ionic liquid. ACS Appl Mater Interfaces, 2010, 2(4): 1120-1128. https://doi.org/10.1021/am9009082 
[16] Nomura A, Okayasu K, Ohno K, et al. Lubrication mechanism of concentrated polymer brushes in solvents: effect of solvent quality and thereby swelling state. Macromolecules, 2011, 44(12): 5013-5019. https://doi.org/10.1021/ma200340d

[17] Chen M, Briscoe WH, Armes SP, et al. Polyzwitterionic brushes: Extreme lubrication by design. European Polymer Journal, 2011, 47(4): 511-523. https://doi.org/10.1016/j.eurpolymj.2010.10.007

[18] Kobayashi M, Terada M and Takahara A. Reversible adhesive-free nanoscale adhesion utilizing oppositely charged polyelectrolyte brushes. Soft Matter, 2011, 7(12): 5717-5722. https://doi.org/10.1039/c1sm05132f

[19] Nomura A, Ohno K, Fukuda T, et al. Lubrication mechanism of concentrated polymer brushes in solvents: effect of solvent viscosity. Polymer Chemistry, 2012, 3(1): 148-153. https://doi.org/10.1039/C1PY00215E

[20] Kobayashi M, Terayama Y, Yamaguchi H, et al. Wettability and antifouling behavior on the surfaces of superhydrophilic polymer brushes. Langmuir, 2012, 28(18): 7212-7222. https://doi.org/10.1021/la301033h

[21] Bielecki RM, Benetti EM, Kumar D, et al. Lubrication with oil-compatible polymer brushes. Tribology Letters, 2012, 45(3): 477-487. https://doi.org/10.1007/s11249-011-9903-6

[22] Kobayashi M, Tanaka H, Minn M, et al. Interferometry study of aqueous lubrication on the surface of polyelectrolyte brush. Acs Applied Materials \& Interfaces, 2014, 6(22): 20365-20371. https://doi.org/10.1021/am505906h

[23] Mocny P and Klok H-A. Tribology of surface-grafted polymer brushes. Molecular Systems Design \& Engineering, 2016, 1(2): 141-154. https://doi.org/10.1039/C5ME00010F

[24] Orski SV, Fries KH, Sontag SK, et al. Fabrication of nanostructures using polymer brushes. Journal of Materials Chemistry, 2011, 21(37): 14135-14149. https://doi.org/10.1039/c1jm11039j

[25] McCutchen CW. The frictional properties of animal joints. Wear, 1962, 5(1): 1-17. https://doi.org/10.1016/0043-1648(62)90176-X

[26] Yu Y, Sun H and Cheng C. Brush polymer-based nanostructures for drug delivery. In: Nanostructures for Drug Delivery. Elsevier, 2017: 271-298. https://doi.org/10.1016/B978-0-323-46143-6.00008-7

[27] Ünal H. Antibiofilm Coatings. In: Handbook of Antimicrobial Coatings. Elsevier, 2018: 301-319. https://doi.org/10.1016/B978-0-12-811982-2.00015-9

[28] Jain P, Baker GL and Bruening ML. Applications of Polymer Brushes in Protein Analysis and Purification. Annual Review of Analytical Chemistry, 2009, 2(1): 387-408. https://doi.org/10.1146/annurev-anchem-060908-155153

[29] Dėdinaitè A. Biomimetic lubrication. Soft Matter, 2012, 8(2): 273-284. https://doi.org/10.1039/C1SM06335A

[30] Chen M, Briscoe WH, Armes SP, et al. Lubrication at Physiological Pressures by Polyzwitterionic Brushes. Science, 2009, 323(5922): 1698-1701. https://doi.org/10.1126/science.1169399

[31] Raviv U, Giasson S, Kampf N, et al. Lubrication by charged polymers. Nature, 2003, 425(6954): $163-165$. https://doi.org/10.1038/nature01970

[32] Kobayashi M and Takahara A. Tribological properties of hydrophilic polymer brushes under wet conditions. Chemical Record, 2010, 10(4): 208-216. https://doi.org/10.1002/tcr.201000001

[33] Bielecki RM, Crobu M and Spencer ND. Polymer-Brush Lubrication in Oil: Sliding Beyond the Stribeck Curve. Tribology Letters, 2013, 49(1): 263-272. https://doi.org/10.1007/s11249-012-0059-9

[34] M. Espinosa-Marzal R, M. Bielecki R and D. Spencer N. Understanding the role of viscous solvent confinement in the tribological behavior of polymer brushes: a bioinspired approach. Soft Matter, 2013, 9(44): 10572-10585. https://doi.org/10.1039/c3sm51415c

[35] Bielecki RM, Doll P and Spencer ND. Ultrathin, Oil-Compatible, Lubricious Polymer Coatings: A Comparison of Grafting-To and Grafting-From Strategies. Tribology Letters, 2013, 49(1): 273-280. https://doi.org/10.1007/s11249-012-0065-y

[36] Ma L, Gaisinskaya-Kipnis A, Kampf N, et al. Origins of hydration lubrication. Nature Communications, 2015, 6(1): 6060 . https://doi.org/10.1038/ncomms 7060

[37] Kajinami N and Matsumoto M. Polymer brush in articular cartilage lubrication: Nanoscale modelling and simulation. Biophysics and Physicobiology, 2019, 16: 466-472. https://doi.org/10.2142/biophysico.16.0_466

[38] Liu G, Liu Z, Li N, et al. Hairy Polyelectrolyte Brushes-Grafted Thermosensitive Microgels as Artificial Synovial Fluid for Simultaneous Biomimetic Lubrication and Arthritis Treatment. Acs Applied Materials \& Interfaces, 2014, 6(22): 20452-20463. https://doi.org/10.1021/am506026e 
[39] Andronescu E and Grumezescu AM. Nanostructures for drug delivery. Amsterdam, Netherlands: Elsevier, 2017: 985. (Nanostructures in therapeutic medicine series).

[40] Sano K, Nakajima T, Choyke PL, et al. Markedly Enhanced Permeability and Retention Effects Induced by Photo-immunotherapy of Tumors. ACS Nano, 2013, 7(1): 717-724. https://doi.org/10.1021/nn305011p

[41] Yu Y, Chen C-K, Law W-C, et al. A degradable brush polymer-drug conjugate for pH-responsive release of doxorubicin. Polym Chem. 2015;6(6):953-61. https://doi.org/10.1039/C4PY01194E

[42] Du J-Z, Tang L-Y, Song W-J, et al. Evaluation of Polymeric Micelles from Brush Polymer with Poly( $\varepsilon$-caprolactone)- b -Poly(ethylene glycol) Side Chains as Drug Carrier. Biomacromolecules, 2009, 10(8): 2169-2174. https://doi.org/10.1021/bm900345m

[43] Zhao P, Liu L, Feng X, et al. Molecular Nanoworm with PCL Core and PEO Shell as a Non-spherical Carrier for Drug Delivery. Macromolecular Rapid Communications, 2012, 33(16): 1351-1355. https://doi.org/10.1002/marc.201200172

[44] Johnson JA, Lu YY, Burts AO, et al. Drug-Loaded, Bivalent-Bottle-Brush Polymers by Graft-through ROMP. Macromolecules, 2010, 43(24): 10326-10335. https://doi.org/10.1021/ma1021506

[45] Johnson JA, Lu YY, Burts AO, et al. Core-Clickable PEG- Branch -Azide Bivalent-Bottle-Brush Polymers by ROMP: Grafting-Through and Clicking-To. Journal of the American Chemical Society, 2011, 133(3): 559-566. https://doi.org/10.1021/ja108441d

[46] Yu Y, Chen C-K, Law W-C, et al. Well-Defined Degradable Brush Polymer-Drug Conjugates for Sustained Delivery of Paclitaxel. Molecular Pharmaceutics, 2013, 10(3): 867-874. https://doi.org/10.1021/mp3004868

[47] Zou J, Yu Y, Li Y, et al. Well-defined diblock brush polymer-drug conjugates for sustained delivery of paclitaxel. Biomaterials science, 2015, 3(7): 1078-1084. https://doi.org/10.1039/C4BM00458B

[48] Yang YQ, Zheng LS, Guo XD, et al. pH-Sensitive Micelles Self-Assembled from Amphiphilic Copolymer Brush for Delivery of Poorly Water-Soluble Drugs. Biomacromolecules, 2011, 12(1): $116-122$. https://doi.org/10.1021/bm101058w

[49] Nowinski AK, Sun F, White AD, et al. Sequence, Structure, and Function of Peptide Self-Assembled Monolayers. Journal of the American Chemical Society, 2012, 134(13): 6000-6005. https://doi.org/10.1021/ja3006868

[50] White AD, Nowinski AK, Huang W, et al. Decoding nonspecific interactions from nature. Chemical Science, 2012, 3(12): 3488-3494. https://doi.org/10.1039/c2sc21135a

[51] Gottenbos B, van der Mei HC, Klatter F, et al. In vitro and in vivo antimicrobial activity of covalently coupled quaternary ammonium silane coatings on silicone rubber. Biomaterials, 2002, 23(6): $1417-$ 1423. https://doi.org/10.1016/S0142-9612(01)00263-0

[52] Gudipati CS, Finlay JA, Callow JA, et al. The Antifouling and Fouling-Release Perfomance of Hyperbranched Fluoropolymer (HBFP)-Poly(ethylene glycol) (PEG) Composite Coatings Evaluated by Adsorption of Biomacromolecules and the Green Fouling Alga Ulva. Langmuir, 2005, 21(7): 3044-3053. https://doi.org/10.1021/la048015o

[53] Lienkamp K, Madkour AE, Kumar K, et al. Antimicrobial Polymers Prepared by Ring-Opening Metathesis Polymerization: Manipulating Antimicrobial Properties by Organic Counterion and Charge Density Variation. Chemistry - A European Journal, 2009, 15(43): 11715-11722. https://doi.org/10.1002/chem.200900606

[54] Cheng G, Li G, Xue H, et al. Zwitterionic carboxybetaine polymer surfaces and their resistance to long-term biofilm formation. Biomaterials, 2009, 30(28): 5234-5240. https://doi.org/10.1016/j.biomaterials.2009.05.058

[55] Zhang Z, Zhang M, Chen S, et al. Blood compatibility of surfaces with superlow protein adsorption. Biomaterials, 2008, 29(32): 4285-4291. https://doi.org/10.1016/j.biomaterials.2008.07.039

[56] Kathmann EE, White LA and McCormick CL. Water soluble polymers: 70. Effects of methylene versus propylene spacers in the $\mathrm{pH}$ and electrolyte responsiveness of zwitterionic copolymers incorporating carboxybetaine monomers. Polymer, 1997, 38(4): 879-886. https://doi.org/10.1016/S0032-3861(96)00587-3

[57] Viklund C and Irgum K. Synthesis of porous zwitterionic sulfobetaine monoliths and characterization of their interaction with proteins. Macromolecules, 2000, 33(7): 2539-2544. https://doi.org/10.1021/ma991965+

[58] Cao B, Tang Q, Li L, et al. Switchable antimicrobial and antifouling hydrogels with enhanced mechanical properties. Advanced Healthcare Materials, 2013, 2(8): 1096-1102. https://doi.org/10.1002/adhm.201200359

[59] Bernards MT, Cheng G, Zhang Z, et al. Nonfouling polymer brushes via surface-initiated, twocomponent atom transfer radical polymerization. Macromolecules, 2008, 41(12): 4216-4219. https://doi.org/10.1021/ma800185y 
[60] Cheng G, Xue H, Zhang Z, et al. A switchable biocompatible polymer surface with self-sterilizing and nonfouling capabilities. Angewandte Chemie, 2008, 120(46): 8963-8966. https://doi.org/10.1002/ange.200803570

[61] Yang W, Lin P, Cheng D, et al. Contribution of charges in polyvinyl alcohol networks to marine antifouling. ACS Appl Mater Interfaces, 2017, 9(21): 18295-18304. https://doi.org/10.1021/acsami.7b04079

[62] Yandi W, Mieszkin S, di Fino A, et al. Charged hydrophilic polymer brushes and their relevance for understanding marine biofouling. Biofouling, 2016, 32(6): 609-625. https://doi.org/10.1080/08927014.2016.1170816

[63] Di Fino A, Petrone L, Aldred N, et al. Correlation between surface chemistry and settlement behaviour in barnacle cyprids (Balanus improvisus). Biofouling, 2014, 30(2): 143-152. https://doi.org/10.1080/08927014.2013.852541

[64] Majumdar P, Lee E, Patel N, et al. Development of environmentally friendly, antifouling coatings based on tethered quaternary ammonium salts in a crosslinked polydimethylsiloxane matrix. Journal of Coatings Technology \& Research, 2008, 5(4): 405. https://doi.org/10.1007/s11998-008-9098-4

[65] Yang W, Zhao W, Liu Y, et al. The effect of wetting property on anti-fouling/foul-release performance under quasi-static/hydrodynamic conditions. Progress in Organic Coatings: An International Review Journal, 2016, 95: 64-71. https://doi.org/10.1016/j.porgcoat.2016.02.018

[66] Wan F, Pei X, Yu B, et al. Grafting polymer brushes on biomimetic structural surfaces for anti-algae fouling and foul release. Acs Applied Materials \& Interfaces, 2012, 4(9): 4557-4565. https://doi.org/10.1021/am300912w

[67] Du T, Ma S, Pei X, et al. Bio-inspired design and fabrication of micro/nano-brush dual structural surfaces for switchable oil adhesion and antifouling. Small, 2017, 13(4): 1602020. https://doi.org/10.1002/smll.201602020

[68] Sun L, Dai J, Baker GL, et al. High-Capacity, Protein-Binding Membranes Based on Polymer Brushes Grown in Porous Substrates. Chemistry of Materials, 2006, 18(17): 4033-4039. https://doi.org/10.1021/cm060554m

[69] Dai J, Baker GL and Bruening ML. Use of Porous Membranes Modified with Polyelectrolyte Multilayers as Substrates for Protein Arrays with Low Nonspecific Adsorption. Analytical Chemistry, 2006, 78(1): 135-140. https://doi.org/10.1021/ac0513966

[70] Bratek-Skicki A, Cristaudo V, Savocco J, et al. Mixed Polymer Brushes for the Selective Capture and Release of Proteins. Biomacromolecules, 2019, 20(2): 778-789. https://doi.org/10.1021/acs.biomac.8b01353

[71] Jiang L and Ye L. Nanoparticle-supported temperature responsive polymer brushes for affinity separation of histidine-tagged recombinant proteins. Acta biomaterialia, 2019, 94: 447-458. https://doi.org/10.1016/j.actbio.2019.04.056

[72] Trmcic-Cvitas J, Hasan E, Ramstedt M, et al. Biofunctionalized Protein Resistant Oligo(ethylene glycol)-Derived Polymer Brushes as Selective Immobilization and Sensing Platforms. Biomacromolecules, 2009, 10(10): 2885-2894. https://doi.org/10.1016/j.actbio.2019.04.056 